\title{
MINOR ELEMENT GEOCHEMISTRY OF LAKE MICHIGAN FERROMANGANESE NODULES *
}

\author{
David N.EDGINGTON \\ Argonne National Laboratory, Argonne, Illinois, USA \\ and \\ Edward CALLENDER \\ University of Michigan, Ann Arbor, Michigan, USA
}

Received 3 March 1970

\begin{abstract}
Samples of ferromanganese nodules from several localities in Lake Michigan have been analyzed for their minor element content utilizing neutron activation techniques. The thorium and uranium levels in Lake Michigan nodules exhibit marked dissimilarities with marine nodules. The radium content of these freshwater nodules is substantially higher than the reported marine values.

The concentrations of barium in the Lake Michigan nodules appear to be abnormally high. Although harium could be present as minute segregations of the mineral barite, patterns obtained using the electron microprobe suggest it is evenly dispersed throughout the nodules. The average arsenic content of these freshwater nodules is at least twice as great as that reported for highly oxidized marine sediments. If all this arsenic is dissolved and released into Green Bay as a result of changing environmental conditions (eutrophication), the concentration in the water of Green Bay would be several times the maximum permissible level for drinking water.
\end{abstract}

\section{Introduction}

Ferromanganese nodules have been discovered recently in Lake Michigan with major concentrations occurring in Green Bay and Little Traverse Bay. Rossmann and Callender have reported analyses for the major constituents in these nodules $[1,2]$, and Harriss and Troup have reported similar results for nodules found in smaller Canadian lakes [3]. These authors have compared their results with those found for marine nodules $[4,5]$.

In an attempt to learn more about freshwater ncdules. ten samples of ferromanganese nodules have been analyzed by neutron activation techniques makin/s use of chemical separations and a least squares

* Contribution 116 of the Great Lakes Research Division, the Jniversity of Michigan. Work performed under the auspices of the U.S. Atomic Energy Commisston. resolution of the gammia-ray spectra obtained $[6,7]$. The concentration of radium was determined by the radon amanation technique [8]. Twenty elements were detected in the sarnples analyzed. In addition, a few individual nodule; from Green Bay have been examined using the eiectron probe $\mathrm{X}$-ray microanalyzer [9].

\section{Results}

The resilts of these determinations by neutron activation analysis are summarized in table 1. Samples were collecied from six locations in Green Bay (fig. 1) on the western edge of Lake Michigan and three in Little Traverse Bay on the northeast side. The results are expressed as parts per million of the total dried $\left(110^{\circ} \mathrm{C}\right)$ sample. The nodules contain from $20-50 \%$ of insoluble material which, from preliminary analyses, 


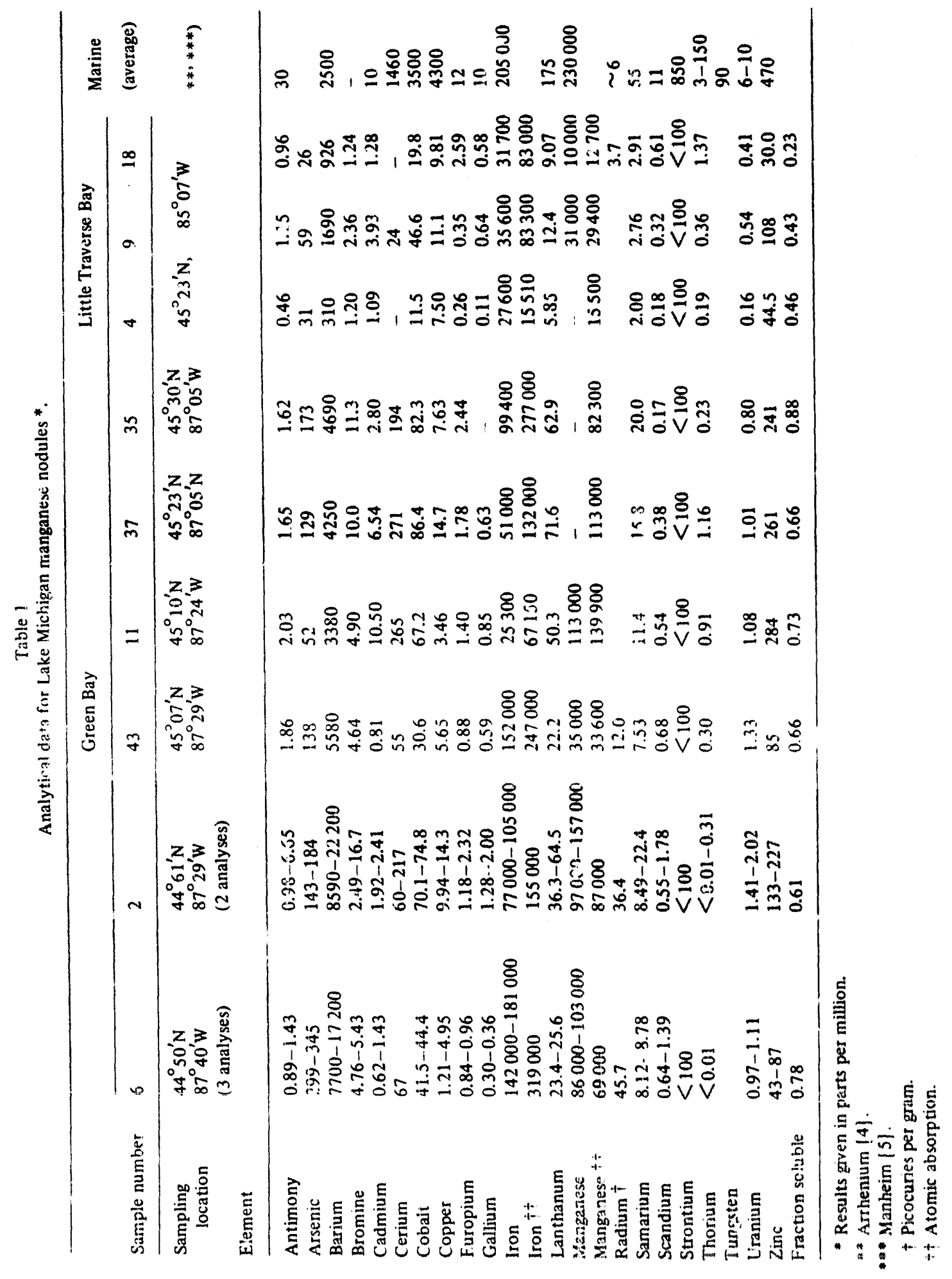




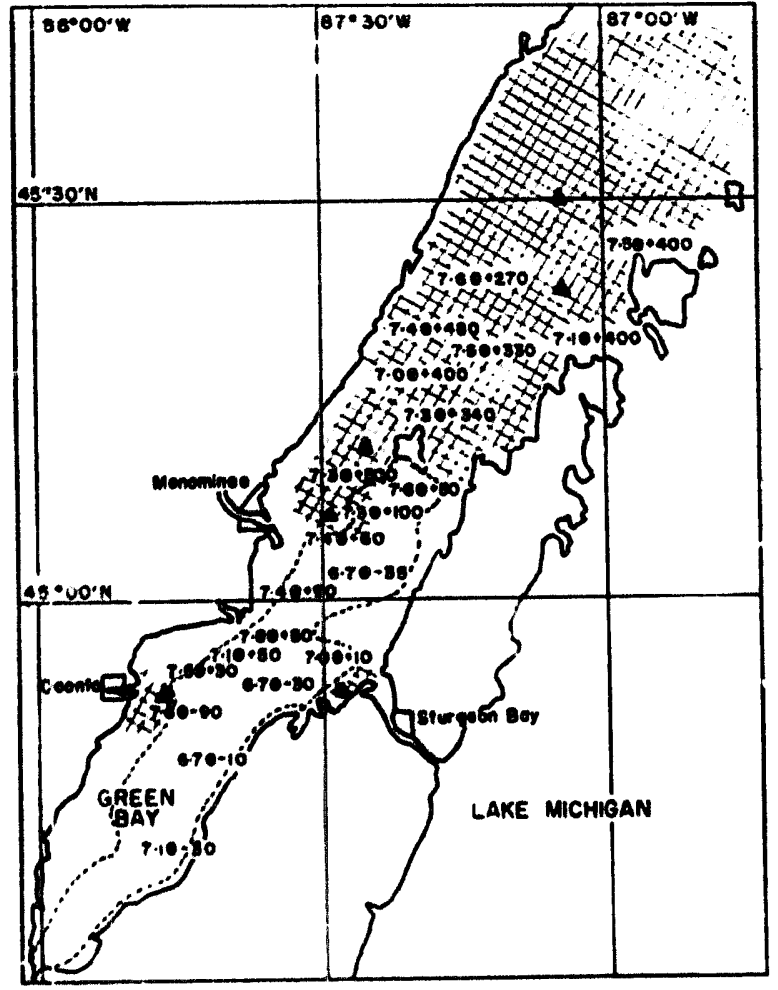

F g. I. Map of Green Bay showing limits of reduced and oxidizing bottom sediments. The cross hatched areas are highly oxidizing. while the limits of reduced sediments are designated by a broken line. 4 : Locility of nodules taken for analysis: pil - Eh: Locality where pH and Eh of sediment measured.

appear to consist primarily of detrital silicates which are not an integral part of the ferromanganese material.

The results found for the more conmon transition elements in these nodules (e.g., $\mathrm{Cu}, \mathrm{Zn}, \mathrm{Co}, \mathrm{Fe}, \mathrm{Mn}$ ) ate in agreement with those already reported for Lake Michigan concretions $[1,2\}$. These values are generally lower than those reported for Canadian lakes [3] and the marine environment $[4,5]$.

However, the concentrations of other, less common elements which we have analyzed appear to be of great interest. In particular, mention should be made of the comparatively large concentrations of arsenic found in the Lake Michigan nodules. Analyses for this element in marine or freshwater nodules have not been reported, apart from values of $500-1000$ $\mathrm{ppm}$ found by Sevast'yanov in ferromanganese concentratiuns from the Black Sea $[10]$.
The concentration of barium in these noduies is significantly higher than that found in marine concretions. Several nodules were examined for the distribution of barium using the electron microprobe. Preliminary results indicated that barium is uniformly distributed throughout the nodules and is probably associated more with manganese than iron [9].

The concentrations of the naturally occurring alpha-emitters, radiunı, thorium and uranium, show marked differences from those reported for marine nodules. In the freshwater nodules the concentration of radium is up to ten times higher, thorium varies two to four orders of magnitude lower, and uranium is of the same order of magnitude as the marine values [11].

Because of the similarities between the chemistry of manganese and rhenium, and the fact that rhenium is found in samples of fish from Lake Michigan [7], this element was specifically sought but not found in any of the samples.

\section{Discussion}

In a previous paper it has been shown that Lake Michigan nodules exhibit no specific X-ray pattern except for detrital quartz and feldspar grains [2]. The preliminary results obtained using the electron probe microanalyzer have shown that most of the major constituents are uniformly distributed throughout these nodules. These data indicate that, unlike the marine nodules, barium is associated almost entirely with the uncharacterized amorphous ferromanganese compounds.

The high concentration of radium in these freshwater nodules is not unexpected in light of their concomitant elevated barium concentrations and the greater concentration of radium in the freshwater envirorment (freshwater $-0.4 \mathrm{pC} / 1$, sea water $0.06 \mathrm{pCi} / \mathrm{l})[12]$. The concentration of thorium in these nodu'es is two or more orders 't magnitude less than narine mitcria!, while the concentration of uranium is approximately a facto: of ten lower. The large concentration of thorium relative to uranium in marine nodules (in spite of uranium having a sixtyfuld greater concentration in sca water) is due to the fact that ferromanganese nodules form under highly oxidizing conditions. Uranium is preferentially oxidized to the hexavalent state and forms anionic car- 
bonate ion complexes which are not adsorbed by the hydroxide colloid, while the thorium in the tetravalent state is preferentially adsorbed. The ratio of uranium to thorium in the freshwater environment is approximately the same as that found in the ocean, but one othe ${ }_{i}$ important condition may be different. The freshwater nodules are not fo:med in as highly oxidizing an environinent as the drep-sea nodules and therefore it is not so certain that uranium is oxidized to the hexavalent state and complexed by carbonate $[2,13]$.

The high concentrations of arsenic in most of the samples may be of very great importance. There is no way to tell whether the concentration of arsenic is due to recent industrial and agricultural activity. However, it may be significant that the highest values are found off Oconto where the Oconto River drains into the bay.

The survey work co ndicted in Green Buy has shown that these nodules are found only under aerobic conditions [2]. In ig. 1 we have indicated those areas where nodules ar: found, the area where anaerobic conditions exist, as well as the values of pit and Eh of the sediments in the general area. In the southern end of Green Bay, where eutrophicalion is advanced and anaerobic conditions exist, the value of the Eh is $\leqslant 100 \mathrm{mV}$; no nodules are found. In contrast, for those conditions where nodules are found, and this includes a large propurtion of Green Bay, the value of the $\mathrm{Eh}$ is $>200 \mathrm{mV}$. Therefore, if Green Bay continues to be polluted, there is a distinct possibility that ihese sodules will go into solution and release this arsenic into the lake. A conservative estimate for the concentration of nodules in Green Bay is $10^{8}$ netric tons. Is the average arsenic concentration in these nodules is $0.0180 \%$ then there is a total of $1.8 \times 10^{4}$ metric tons of arsenic. The volume of water in Green Bay is estimated to be $200 \mathrm{~km}^{3}$ (four percent of the total volume of Lake Michigan). By simple arithmetic 1 mel.ric ton $/ \mathrm{km}^{3}=1 \mu \mathrm{g} / \mathrm{l}$. Therefore, if all the nodules believed to be in Green Bay dissolve because of the water becoming anaerobic and more acidic, the resulting concentration of arsenic, which is highly toxic to mammals and also carcinogenic, will be approximately $90 \mu \mathrm{g} / \mathrm{l}$. The con. :ntration in the whole of Lake Michigan, assumirg perfect mixing, wrould be $3.6 \mathrm{\mu g} / \mathrm{l}$. The recommended value tor arsenic in drinking water, if no better supply is available, is $50 \mu \mathrm{g} / \mathrm{l}$ and the most desirable value is $10 \mu \mathrm{g} / 1$ [14]. Since the residence time of any solubie chemical species in Lake Michigan with respect to outflow is 100 years, this: contamination may be long-lasting [15].

It is evident from these gross approximations that these nodules, while of possible commercial interest, may also pose an environmental problem if the advance of pollution in Green Bay is not abated. The environmental controls for such a toxic element in natural waters must be defined further in order to evaluate the potential health hazard from these nodules.

\section{References}

[1] R.Rossmann and E.Callender, Manganese nodules in Lake: Michigan, Science 162 (1968) 1123.

[2] R.Rossmann and E.Caliender, Geochemistry of Lake Michigan manganese nc dules, Proc. 12th Conf. on Great Lakes Research (1970) 306.

|3| R.C.Harriss and A.G.Troup, Freshwater ferromanganese concretions: chemistry and internal structure, Scien e $166(1969) 604$.

14] G.Arrhenius, Pelagic sediment, in: The Sea, ed. M.N. Hill, vol. 3 (Wiley, New York, 1963 ).

|5| F.T.Manheim, Mangane se-iro 7 accumulations in the shallow marine environnent, ir: Symposium on Marine Chemistry, Occasional Publication no. 3-1965 (Line of Rhode lsland, Kingston, 1355 ) p. 217.

|6| D.N.Edgington. The estimation of thorlum and uranium at the submicrogram level in bone by neutron activation, Intern. J. Appl. Radiation Iscitopes 18 (1967) 11.

[7] D.N.Fdginton and H.F.Lucas, Jr., A system for the neutron activation analysis of trace elements in samples of biological and environmental interest, Argonne Nat. Lab. Rev. 5 (1969) 98.

[8] H.F.Lucas, Jr., Improved low-level alpha scintillation counter for radon, Rev. Sci. Instr. 28 (1957) 680.

[9] E.Callender, unpublished rest lis.

[10] V.F.Sevast yanov, Redistribution of arsenic, accompanying the formation of iron-marganese concentrations in Black Sea deposits, Dokl. Acild Nauk. SSR 176 (1967) 191.

[11] J.Buchowicki and R.D.Cherry, Thorium, radium, and potassium in manganese podules, Chem. Geol. $3(1968)$ 111.

112] H.J.M.Bowen, Trace Llements m Bordemistry (Academk Press, New York, 1966).

$113 \mid$ D.C.Lynn and E. Bonatti, Bobilty of manganese in diagenesis of deep sea sediments, Mar. Geol. $3(1955) 457$

114) FWPCA, Report of the Committee on Water Quality Criteria (Govt. Print. Cifice, Washington, 1968 p. 234.

115 | J.W.Winchester, Pollution pathway's in the Gre: 1 Lakes. L.mnos $2(1969) 20$. 